\title{
Governing 'Ethnicised' Public Sphere: Insights from Nigeria
}

\author{
Nkwachukwu Orji*
}

\begin{abstract}
This article explores the way in which ethnically diverse societies govern their public sphere. It shows that the public sphere in multiethnic societies is an arena of conflict where cultural and ideological contest or negotiation among a variety of groups takes place. Drawing from Nigeria's experience, the article examines the conflict management arrangement devised to regulate hostile inter-group relations in the public sphere. It identifies power-sharing as the most fundamental conflict management strategy adopted to govern Nigeria's public sphere. The article argues that although power-sharing features as the most acceptable modality for moderating inter-group conflicts in Nigeria, its usefulness is limited by the fact that it widens the asymmetrical and oligarchic power of the dominant groups and hampers the growth of democracy.
\end{abstract}

\section{Résumé}

Cet article étudie comment des sociétés ethniquement diverses gouvernent leur sphère publique. Il montre que la sphère publique dans les sociétés multiethniques est une arène de conflit dans laquelle se déroule la contestation ou la négociation culturelle et idéologique entre divers groupes. S'inspirant de l'expérience du Nigeria, l'article examine les dispositions en matière de gestion de conflit visant à réglementer les rapports intergroupes hostiles dans la sphère publique. Il identifie le partage de pouvoir comme étant la stratégie de gestion de conflit la plus fondamentale adoptée pour régir la sphère publique nigériane. L'article soutient que bien que le partage du pouvoir se présente comme la modalité la plus acceptable pour modérer les conflits intergroupes au Nigeria, son utilité est limitée par le fait qu'il élargit le pouvoir asymétrique et oligarchique des groupes dominants et entrave le développement de la démocratie.

* Department of Political Science, Ebonyi State University, Abakaliki, Nigeria. Email:nkwaorji@yahoo.com 


\section{Introduction}

Nigeria's heritage of ethnic diversity has had an overwhelming impact on the country's public sphere, leading to its 'ethnicisation'. On the other hand, the stiff political competition among the elite has resulted in the 'politicisation' of ethnicity in the country. The result of the above is a highly contested public sphere, which has been made the arena of rhetorical confrontations between various ethnic groups in the country. However since the 1970s, the Nigerian political elite have adopted power-sharing as a strategy to manage inter-group relations, mitigate the negative effects of ethnic politics, and transform the 'ethnicised' public sphere through the introduction of the discourse of 'unity in diversity'. The adoption of power-sharing is an outcome of the elite soul-searching that followed the end of the Nigerian civil war in 1970 as well as a result of changes in the nature of federal-state relations in the country (see Orji 2008). Power-sharing in Nigeria expresses the tendency of the elite to govern the public space, manage ethnic diversity, and promote a Nigerian State project by avoiding divisive politics and emphasizing ethno-regional equilibrium in resource distribution.

This article analyses power-sharing as a conflict management strategy for governing Nigeria's public sphere. It argues that power-sharing is an arrangement developed to resolve the contestations among the plurality of competing groups. The article is organised into six sections. Following this introductory section is the second section that reflects on the meaning of the concept of public sphere in Africa. The third section examines efforts to manage conflicts in Nigeria's public sphere through the practice of powersharing. The fourth section looks at how the practice of power-sharing shapes Nigeria's public sphere, while the fifth section deals with the challenges and opportunities of governing the public sphere through powersharing. The paper ends in the sixth section with a conclusion.

\section{The African Public Sphere: A Conceptual Reflection}

The concept of public sphere was popularised by German historian Jurgen Habermas. Habermas sees the public sphere as 'a realm of social life in which something approaching public opinion can be formed' (Habermas 1974:49). This realm represents an arena where people gather together to freely discuss and identify societal problems, and through discussion influence political action. The public sphere as a discursive space mediates between the 'private sphere' and the 'sphere of public authority'. The private sphere comprises the civil society while the state makes up the sphere of public authority. Habermas notes that newspapers, magazines, radio and television are the key media of the contemporary public sphere and agencies through 
which the authority of the state can be regulated. The media of mass communication promote the idea of participatory democracy by providing the framework for the formation of public opinion and the translation of the opinion into political action. Habermas distinguishes between literary and political public spheres. The political public sphere is the arena for public discussion of issues which are connected to the activity of the state, while the literary public sphere offers the people the freedom of assembly and association as well as the freedom to express and publish their opinions about matters of general interest. The major actors in the political public sphere are social organisations which deal with the state. Often, these organisations relate directly with state institutions or indirectly through the political parties (see Ferree, Gamson, Gerhards and Rutch 2002).

In his analysis of the development of public sphere in Western Europe, Habermas identifies three major institutional criteria underlying the emergence of the public sphere. The first is disregard of status. Here, it is assumed that the public sphere promotes 'a kind of social intercourse that, far from presupposing the equality of status, disregarded status altogether' (Habermas 1989:36). The second criterion is that the public sphere must constitute a domain of common concern. By 'domain of common concern', Habermas maintains that discussion in the public sphere should highlight issues that affect the well-being of the entire society as well as problematize issues that have not been previously questioned. Lastly, there is the criterion of inclusivity, which requires that the public sphere must not 'close itself off entirely and become consolidated as a clique' (Habermas 1989:36). Rather, the public sphere should represent an 'inclusive public of all private people, persons who - insofar they were propertied and educated - as readers, listeners, and spectators could avail themselves via the market of the objects that were subject to discussion' (Habermas 1989:36).

The above 'institutional criteria' outlined by Habermas do not constitute a useful framework for analysing the public sphere for a number of reasons. First, as Nancy Fraser (1990) observed, the criteria do not fit the reality, because Habermas' bourgeois public sphere was characterised by hegemonic dominance and exclusion rather than inclusivity and disregard for status. Fraser claims that the Habermas' public sphere discriminated against women and people in the lower social strata of the society. She maintains that the bourgeois public sphere was an arena for recruiting bourgeois men into governing positions and, as such, the sphere was made inaccessible to people considered inferior based on their gender, social status, ethnicity, and property ownership. Fraser also noted the difficulties associated with defining Habermas' criterion of 'common concern'. To her, 'there are no naturally given, a priori boundaries' between private and public matters or matters of 
common concern (Fraser 1990:57). She cites the case of domestic violence, a matter previously regarded as private, but which has now been generally accepted as a common concern. In all, Fraser asserts that Habermas' bourgeois public sphere did not offer a new, all-inclusive political realm. Rather, it shifted political power from 'a repressive mode of domination to a hegemonic one' in which rule by power is replaced with rule by the majority ideology (Fraser 1990:62).

Another contested issue regarding Habermas' theory of public sphere is the question of whether, and to what extent, the theory could be applied to countries outside Western Europe. I will argue that Habermas' conception of the public sphere is not applicable to many African countries for two reasons. The first reason follows an argument developed by Philip Huang (1993) that Habermas formulated his theory of public sphere as a Western European phenomenon, which is too historically specific to be a guide for analysing public sphere elsewhere. The second reason points to Habermas' treatment of the public sphere as a 'single, comprehensive public sphere' (Fraser 1990:62); and his failure to consider the fact that public sphere in some countries is constituted by a plurality of competing publics. Habermas' approach negated the warning by Peter Ekeh (1975:92), that the 'extension of the Western conception of politics in terms of a monolithic public realm morally bound to the private realm can only be made at conceptual and theoretical peril'. Thus, the Habermasian conception of the public sphere is theoretically inadequate and falls short of being a useful guide for analysing the public sphere in the African countries with multiplicity of competing publics.

A look at many African countries shows that public life is not confined to a single, all-embracing public sphere as Habermas envisaged. Instead, there exists a multiplicity of publics that relate with each other. In the 1970s, Peter Ekeh (1975:91) noted that 'the experiences of colonialism in Africa have led to the emergence of a unique historical configuration in modern post-colonial Africa: the existence of two publics instead of one public, as in the West'. The two publics include the primordial public - in which primordial groupings, ties, and sentiments influence and determine the individual's public behaviour, and the civic public - which relates to Habermas' 'sphere of public authority' and based on civil structures such as the civil service, police, and the military. These publics follow the lines of social identity, including ethnic, race, class, religion, age and gender.

In many parts of Africa, ethnicity is still the most dominant form of identity. The tendency for individuals in the public sphere to identify themselves or to be identified with a specific ethnic group has resulted in the atomisation of the public sphere along ethnic lines. ${ }^{1}$ In the 'ethnicised' 
public sphere, the relations between the ethnic publics are usually conflictual because the rhetorical contestation among the publics is a part and parcel of overarching struggle by the ethnic groups to capture and dominate the state. In this circumstance, the marginal groups contest the primacy of the dominant groups, highlighting alternative ways to organise political relations and the society in general. The dominant groups, in turn, try hard to undercut the proposed alternatives and deliberately seek to block pressures for reform or change in the discourses.

The inter-group contestation that takes place in the public sphere makes it an arena of conflict, especially between the marginal and dominant ethnic groups. Eley (1991) agrees with this view, noting that the public sphere is a 'structured setting where cultural and ideological contest or negotiation among a variety of publics takes place'. The African public sphere can therefore be conceptualised as a discursive arena where elites from different ethnic groups invent and circulate discourses and counter-discourses, which help them to 'formulate oppositional interpretation of their identities, interests, and needs' (Fraser 1990:67). Now, one key problem that confronts multiethnic societies is how to devise institutional arrangements that would moderate hostile interethnic relations in the public sphere. Thus, governing the public sphere has become part and parcel of the state and nation-building efforts in Africa, as the Nigerian case illustrates.

\section{Conflict Management in Nigeria's Public Sphere}

Nigeria presents us with an interesting case of how to deal with inter-group tension in an 'ethnicised' public sphere. Elites from five major ethno-regional groups (the North, Yoruba, Igbo, Niger Delta and Middle Belt) dominate the present-day Nigerian public sphere. These ethno-regional elite groups developed along the ethno-regional boundaries created by the colonial and post-colonial governments (Nolutshungu 1990:89). These elites are essentially politicians who have a privileged access to the state, but there are also traditional rulers, senior military officers, administrators, professionals, academics and businessmen (Madunagu 1994:15). The ethno-regional elite groups in Nigeria fit into a hierarchy of status and power based on their political influence. The political influence of each elite group is a function of many factors among which demographical, historical, administrative and economic factors are most prominent. Currently, the Northern elite are undoubtedly the leading group, followed by the Yoruba, Igbo, Niger Delta and Middle Belt elites, respectively. This hierarchy is certainly not static; there are possibilities of shifts depending on how much influence a group wields at any particular time. 
The dominant feature of Nigeria's public sphere is a relationship of contestation between the country's ethno-regional elite groups. The key element in the dispute is the deep-seated fear of ethnic domination. However, an interesting aspect of inter-group relations in Nigeria is the existence of a relative balance of power among the groups - in the sense that the groups with the numerical capacity to dominate majoritarian electoral contest do not have the requisite human capital to dominate the state institutions (see Sklar 1965). Under this circumstance, there appears to be a division of labour between the groups that dominate the national electoral process and the ones that dominate the state institutions. Attempts by the groups to break down this apparent division of labour in the 1960s resulted in intense adversarial elite political competition culminating in a bloody civil war between 1967 and 1970. The soul-searching that followed the civil war reflected in the quest for elite consensus on how Nigeria should be governed to ensure stability and equity in resource distribution. This new mode of elite thinking transformed the Nigerian public sphere as the prime site for negotiating and constructing the processes and frameworks through which the elite seek to realize their interests within non-violent distributive politics.

The main institutional arrangement that has emerged as the modality for regulating tensions in Nigeria's public sphere can be conceptualised as powersharing. Power-sharing can be simply defined as the act of providing 'every significant identity group or segment in a society representation and decisionmaking abilities on common issues and a degree of autonomy over issues of importance to the group' (Sisk 1996:5). The Nigerian political elite have implemented power-sharing through arrangements such as federal character, equity-based revenue allocation system, and states creation. The goal of power-sharing is to manage ethnic diversity and promote the Nigerian state project by emphasising 'unity in diversity'. Through this process, it is hoped that individuals from different ethnic backgrounds would be constrained from acting in ways that would undermine the 'common interest' of all Nigerians.

The basic structure of power-sharing in Nigeria covers three major dimensions - the territorial, fiscal and political. The territorial dimension of power-sharing relates to federalism and creation of states, while the fiscal dimension has to do with the revenue allocation system. Finally, the political dimension of power-sharing deals with office distribution methods. The process of power-sharing in Nigeria corresponds to most of the elements of consociational ${ }^{2}$ and incentivist ${ }^{3}$ models of power-sharing (see Bogaards 2006:122; Horowitz 2002:23, 1991:139-141, 1985:563-680; and Lijphart 1977:16-25). 
Creation of states facilitates sharing of territorial powers through the formation and distribution of federal units. The two forms of states creation prescribed by both the consociational and incentivist models can be identified in Nigeria. First, there is the creation of ethnically homogeneous states, especially among the geographically and demographically large ethnic groups like the Hausa-Fulani, Yoruba and Igbo. Then ethnically heterogeneous states were created to hold together several minority groups. On the fiscal dimension, the revenue allocation system guides the process of allocation of financial resources. This process is dominated by two important processes - revenue allocation is characterised by fiscal centralisation at the vertical level, ${ }^{4}$ while revenue allocation is based on the principle of equality of states at horizontal level. ${ }^{5}$ The political dimension of power-sharing is defined by office distribution, involving two processes - the federal character and zoning. The federal character principle ensures that each state of Nigeria is considered in the selection and recruitment into government agencies while zoning is an informal arrangement in which the states in Nigeria are aggregated into zones or regions for the purpose of allocating offices. These processes correspond to consociationalism's elite coalition and proportional representation.

\section{Power-sharing and Nigeria's Public Sphere}

The practice of power-sharing shapes Nigeria's public sphere in three major ways. First, it induces a shift in the character of public discourse from the 'discourse of ethnic competition' to the 'discourse of ethnic collaboration'. The dominant discourse in the pre-1970 era was the discourse of ethnic competition championed by the political elite who at various times claimed their groups' superiority over the other groups. A widely quoted statement attributed to Igbo leader Nnamdi Azikiwe illustrates this point. Azikiwe was reported as saying that:

...the God of Africa has specially created the Ibo nation to lead the children of Africa from the bondage of the ages...The martial prowess of the Ibo nation at all stages of human history has enabled them not only to conquer others but also to adapt themselves to the role of preserver. The Ibo nation cannot shirk its responsibility (see Coleman 1958:347).

This statement gave credence to fears of Igbo domination by elites from other ethnic groups and provoked them to make counter-rhetoric, which fuelled inter-ethnic tensions. However since the 1970s, following more rigorous implementation of power-sharing measures, there has been an increasing shift towards the discourse of national unity. The following statement illustrates this shift: 
In a country like Nigeria with its diverse peoples and their corresponding diverse political, cultural and economic endowments, true federalism must reflect a genuine attempt to regulate relationship among the groups, as well as a reflection of these identifiable divergences within a framework of national unity... We in Nigeria must evolve our own power-sharing formula, take our own decisions and develop our own institutions anchored on our historical experiences' (Federal Republic of Nigeria 1995:3).

The second way that power-sharing has shaped the Nigerian public sphere is through the regulation of the mobilisation activities of the political elite and political parties. Over the years, new regulations have been introduced to guide the formation and behaviour of political parties. These regulations restrained the formation of ethnic parties, made it difficult for regionallybased parties to be registered, and required parties to demonstrate a crossethnic/regional composition as a pre-condition for their registration and participation in national elections ${ }^{6}$ (see Phillips 1980; Whitaker 1981; Sklar 1981; Diamond 1982). The high point of this political party reform package is the provision requiring parties to display a 'federal character' by including members from two-thirds of all states of Nigeria in their executive council. ${ }^{7}$ These regulations were part of the overall efforts to ensure that Nigerian parties eschew sectional politics and develop national appeal.

Finally, power-sharing has inspired several media censorship rules that seek to control the content and broadcast of political speeches to ensure that they do not contain hate speech or are based on ethnic and other sectional bias. The Electoral Act 2006, for example, outlaws campaigning or broadcasting of materials that are based on ethnic, religious or sectional bias. ${ }^{8}$ The Electoral Act also stipulates that media time shall be allocated equally among the political contestants at similar hours of the day. These regulations mark a striking departure from the previous practice where political groups were allowed to own and operate media agencies at their own discretion. Within the context of power-sharing, there have been efforts to ensure that all political groups are given a fair opportunity to express themselves and project their identities and interests.

\section{Power-sharing in the Public Sphere: Challenges and Opportunities}

The regulation of Nigeria's ethnicised public sphere through the practice of power-sharing holds a number of challenges and possibilities. The tendency of power-sharing to follow a hierarchy of power among the groups poses one of the greatest challenges to inter-group relations in Nigeria. Powersharing in Nigeria is not a partnership of equals. It operates based on a hierarchy of power among the different ethno-regional elite groups. The 
Northern elites are apparently the leading elite group because of the demographical and geographical superiority of the Northern region as well as the relative political cohesiveness of the group. They are followed by the Yoruba, Igbo, Niger Delta and Middle Belt respectively. Many observers believe that power-sharing as it is being practised in Nigeria widens the 'asymmetrical, oligarchic power' of the dominant groups (Agbaje 1998:132). This view has received the most vocal expression by the minority elite groups; especially those of the Niger Delta, with many individuals in the Niger Delta framing the hegemony of the dominant groups as 'internal colonialism' (Naanen 1995:50). The reflection of inter-elite hierarchy of power in powersharing is seen as a strategy by the dominant elite groups, especially the powerful Northern elite, to maintain their leading position. This strategy also includes the cooptation of the elite groups that accept the prevailing sharing arrangement. The problem with this tendency is that it has made inter-ethnic contestations more explosive and elite consensus more elusive. It also contradicts the motive behind the conception and implementation of power-sharing.

There are two other major problems associated with power-sharing in Nigeria. The first is that the practice of power-sharing undercuts participatory democracy. The search for inter-group accommodation has led to the revival of the 'conservative' view of politics espoused by the elite in the 1960s (see Post and Vickers 1973:63; Ekeh 1989:36). This view canvases for the continuation and consolidation of the colonially inherited system of power distribution which favours the three dominant ethno-regional elite groups. As Richard Sklar (1967:527) puts it:

Nigerian conservatives...had a formula for peaceful development...It prescribes the full regionalization of all political organizations capped by an agreement among regional leaders to respect the political status quo and share the fruits thereof on an equitable basis. That conservative tendency was as strong among leaders in the South as among leaders in the North.

This conservative stance has forced the Nigerian public sphere to overly focus on issues relating to ethnic representation rather than holding the state accountable to the society through public opinion.

Even while emphasising elite dominance, the public sphere is far from being transparent. The tendency is for the ruling elite in Nigeria to converge under one or few national parties, ${ }^{9}$ while much of the activities of these parties and the process of national decision-making are based on elite horsetrading without the involvement of the people. Within the parties, the political elite are allowed maximum control over the direction of political discourse and action within their localities without any meaningful space for popular 
participation in politics. This situation breeds one-partyism, suppresses opposition/alternative viewpoints, and foments what is now popularly referred to as 'Godfatherism'. Godfatherism involves handing out of parts of the state, including specific territorial districts, to a group of elites, usually under the leadership of one or more notables who dictate the direction of political discourse and action essentially by use of force (Ibeanu 2007:9). Godfather politics gives prominent political elite (the godfather) the leverage to decide who takes up positions allocated to a particular electoral constituency. Powersharing encourages Godfatherism because it provides the basis for an individual or a small coterie of elites to control power or speak on behalf of an ethnic or regional group - such individuals many times suppress alternative viewpoints, eliminate competition, hijack local/national party organisation and exploit government machinery for private gain (see Omobowale and Olutayo 2007).

The other problem associated with power-sharing in Nigeria is that it sustains the 'rhetoric of marginalization' and creates a 'dependency syndrome'. The practice of power-sharing supports a tendency where groups look up more to what they can receive from the state than what they can contribute in the process of state/nation-building. This mentality reflects in the rhetoric of marginalisation where the dominant public debates often centre on access to share of federal resources (see Ibelema 2000). The problem with conceiving politics merely as the struggle for a share of the 'fruits of power' is that it is hard to determine how much more than nothing the marginal groups would be satisfied with, or how much less than 'all' would please the dominant groups (Nolutshungu 1990:108). This situation fuels inter-group competition in the public sphere and contradicts the essence of power-sharing.

The above challenges notwithstanding, power-sharing has great possibilities for managing conflicts in Nigeria's ethnicised public sphere. First of all, there is a widely shared assumption that a society as large and complex as Nigeria cannot be peacefully governed without some measure of inter-group consensus. Power-sharing features as the most acceptable modality for reaching elite consensus on how Nigeria can be ruled. ${ }^{10}$

\section{Notes}

1. The Nigerian case, where variegated ethnic publics exist along with their associations, newspapers, books, film, lecture series, festivals and local meetings, is a good example.

2. The consociational model sees communal groups as the building blocks of a political order based on elite consensus and group autonomy. The key element in the consociationalism is elite cooperation. The political stability of 
consociational democracies is explained by the cooperation of elites from different groups which transcend cleavages at the mass level. Related to this element are four important defining features of the consociational model. The first is executive power-sharing where each of the main groups shares in executive power in a grand coalition government. The other basic elements of the consociational model are (1) the application of proportionality principle in office distribution and revenue allocation; (2) autonomy or self-government for each group, particularly in matters of cultural concern; (3) veto rights that would enable each group to prevent changes that adversely affect their vital interests.

3. The incentivist model advocates the design of political institutions to provide incentives for elite and mass moderation. The model is based on Donald Horowitz's contention that consociationalism failed to highlight the incentives for elite cooperation and inter-group accommodation. Horowitz claims that even if the elites commit themselves to a consociational arrangement at the outset in a competitive political environment, centrifugal forces emanating from their followers and political opponents may easily undermine the durability of the agreement. He therefore, argues that what is needed to strengthen consociationalism is to create incentives for sustainable elite cooperation and inter-group accommodation. This incentive can spring from modifications in the federal system, especially through states creation as well as by refining electoral systems to encourage vote pooling. Vote pooling refers to an exchange of the votes of their respective supporters by politicians who have been conditioned by the electoral system to be marginally dependent on votes by other groups for electoral victory.

4. This gives greater amount of national revenue to the federal government vis-à-vis the state and local governments.

5. The principles of fiscal centralisation and equality of states are complemented by the centralised system of revenue collection and administration.

6. In specific terms, the Nigerian Constitution states as follows: (1) no association by whatever name shall function as a political party unless it is registered as a political party by the Independent National Electoral Commission (INEC); (2) that associations wishing to be registered as a political party by Independent National Electoral Commission must: (a) register the names and addresses of its national officers with the Independent National Electoral Commission (INEC); (b) make its membership open to every Nigerian, irrespective of his place of origin, sex, religion, or ethnic grouping; (c) register a copy of the association's constitution in the principal office (that is, the headquarters) of the Commission; (d) register every alteration in the Association's registered constitution in the principal office of the Commission within thirty days of such alteration being made; (e) ensure that the name, emblem or motto has no ethnic or religious connotation, and does not give the appearance that the activities of the association are confined to a part only of the geographical area of Nigeria; (f) situate their headquarters in the 
federal capital territory; (g) satisfy the Independent National Electoral Commission that it has a properly established office in each of at least twothirds of the States in the Federation and that officers have been duly elected or, as the case may be, appointed to run the affairs of such branch office (Sections 227-228, The Constitution of the Federal Republic of Nigeria, 1999; see also sections 219-224, The Constitution of the Federal Republic of Nigeria, 1989; and sections 201-204, The Constitution of the Federal Republic of Nigeria, 1979).

7. See Chapter II, Section 15(3) (d), The Constitution of the Federal Republic of Nigeria, 1979. Lagos: Federal Government Press, and Section 229, (1) (b) The Constitution of the Federal Republic of Nigeria, 1999, Lagos, Federal Government Press.

8. See section 105, The Electoral Act 2006, Lagos, The Federal Government Printer.

9. During the Second Republic, NPN was the 'umbrella' political organization; NRC and SDP were the nation-wide parties in the Third Republic, while PDP is the national party of the Fourth Republic.

10. Although some may see it also as a strategy the North has used in getting different ethno-regional elite groups to agree to the rule of the dominant group - the North.

\section{References}

Agbaje, A., 1989, 'Mass Media and the Shaping of Federal Character: A Content Analysis of Four Decades of Nigerian Newspapers (1950-1984)', in Peter Ekeh and Eghosa E. Osaghae, eds, Federal Character and Federalism in Nigeria, Ibadan: Heinemann.

Agbaje, A., 1998, 'The Ideology of Power-sharing: An Analysis of Content, Context and Intent', in Kunle, Amuwo; Adigun, Agbaje; Rotimi, Suberu and Georges, Herault, eds, Federalism and Political Restructuring in Nigeria, Ibadan: Spectrum.

Bogaards, M., 2006, 'Democracy and Power-sharing in Multinational States: Thematic Introduction', International Journal on Multicultural Societies, Vol. 8, No. 2, pp. 119-126.

Coleman, J., 1958, Nigeria: Background to Nationalism, Benin City: Broburg and Wistrom.

Diamond, L., 1982, 'Cleavage, Conflict and Anxiety in the Second Republic', Journal of Modern African Studies, Vol. 20, No. 4, pp. 629-668.

Ekeh, P., 1989, 'The Structure and Meaning of Federal Character in the Nigerian Political System', in Peter Ekeh and Eghosa, E. Osaghae, eds, Federal Character and Federalism in Nigeria, Ibadan: Heinemann.

Ekeh, P., 1975, 'Colonialism and the Two Publics in Africa: A Theoretical Statement', Comparative Studies in Society and History, Vol. 17, No. 1, pp. 91-112. 
Eley, G., 1991, 'Nations, Publics, and Political Cultures: Placing Habermas in the Nineteenth Century’, in Craig Calhoun, ed., Habermas and the Public Sphere, Cambridge, MA: MIT Press.

Federal Republic of Nigeria, 1995, Report of the Constitutional Conference Containing the Resolutions and Recommendations Vol. II, Abuja: National Assembly Press.

Ferree, M.; Gamson, W., Gerhards, J. and Rutch, D., 2002, 'Four Models of the Public Sphere in Modern Democracies’, Theory and Society, Vol. 31, No. 3, pp. 289-324.

Fraser, N., 1990, 'Rethinking the Public Sphere: A Contribution to the Critique of Actually Existing Democracy’, Social Text, Vol. 25/26, pp. 56-80.

Habermas, J., 1974, 'The Public Sphere: An Encyclopedia Article’, New German Critique, Vol. 3, pp. 49-55.

Habermas, J., 1989, The Structural Transformation of the Public Sphere: An Inquiry into a Category of Bourgeois Society, trans. Thomas Burger and Frederick Lawrence, Cambridge: MIT Press.

Horowitz, D., 1985, Ethnic Groups in Conflict, Berkeley: University of California Press.

Horowitz, D., 1991, A Democratic South Africa? Constitutional Engineering in a Divided Society, Berkeley: University of California Press.

Horowitz, D., 2002, 'Constitutional Design: Proposals Versus Processes’ in A. Reynolds ed., The Architecture of Democracy: Constitutional Design, Conflict Management, and Democracy, Oxford: Oxford University Press.

Huang, P., 1993, 'Public Sphere/Civil Society in China?: The Third Realm between State and Society’, Modern China, Vol. 19, No. 2, pp. 216-240.

Ibeanu, O., 2007, Breaking the Promethean Chain: Protecting Popular Electoral Mandates in the South-East Zone of Nigeria, Onitsha: Nigerian Political Science Association (South-East) Chapter.

Ibelema, M., 2000, 'Nigeria: The Politics of Marginalization', Current History, Vol.99, No. 633-641, pp. 211-214.

Lijphart, A., 1977, Democracy in Plural Societies: A Comparative Exploration, New Haven, CT: Yale University Press.

Madunagu, E., 1994, 'Notes on the Power-blocs (1)', The Guardian, 21 April.

Naanen, B., 1995, 'Oil-producing Minorities and the Restructuring of Nigerian Federalism: The Case of the Ogoni People', Journal of Commonwealth and Comparative Politics, Vol. 33, No. 1, pp. 46-78.

Nolutshungu, S., 1990, 'Fragments of a Democracy: Reflections on Class and Politics in Nigeria’, Third World Quarterly, Vol. 12, No. 1, pp. 86-115.

Omobowale, A. and Olutayo, A., 2007, 'Chief Lamidi Adedibu and Patronage Politics in Nigeria', Journal of Modern African Studies, Vol. 45, No. 3, pp. 425-446.

Orji, N., 2008, 'Power-sharing: The Element of Continuity in Nigerian Politics', Unpublished PhD. Thesis, Central European University, Budapest.

Phillips, C., 1980, 'Nigeria’s New Political Institutions, 1975-79', Journal of Modern African Studies, Vol. 18, No. 1, pp. 1-22. 
Post, K., and Vickers, M., 1973, Structure and Conflict in Nigeria, 1960-1966, London: Heinemann.

Sisk, T., 1996, Power Sharing and International Mediation in Ethnic Conflict, Washington, D.C.: United States Institute of Peace Press.

Sklar, R., 1965, 'Contradictions in the Nigerian Political System', Journal of Modern African Studies, Vol. 3, No. 2, pp. 201-213.

Sklar, R., 1967, 'Nigerian Politics in Perspective’, Government and Opposition, Vol. 2, No. 4, pp. 524-539.

Sklar, R., 1981, 'Democracy for the Second Republic', Issue: A Journal of Opinion, Vol. 11, No. 1/2, pp. 14-16.

Whitaker, Jr., C. S., 1981, 'Second Beginnings: The New Political Framework', Issue: A Journal of Opinion, Vol. 11, No. 1/2, pp. 2-13. 